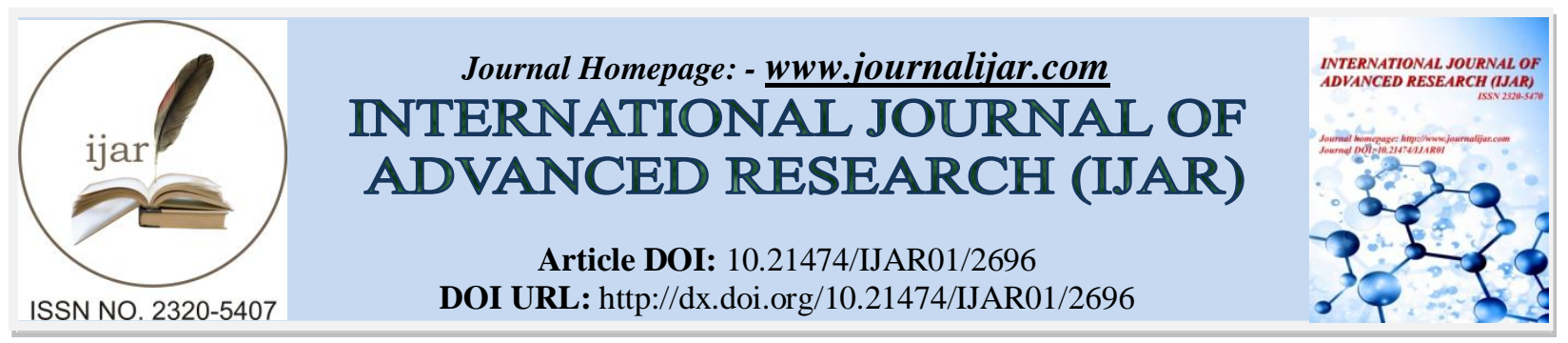

RESEARCH ARTICLE

\title{
AEROBIC BIODEGRADATION OF DAIRY WASTEWATER BY FLUIDIZED BED BIO REACTOR.
}

\author{
Sumithra Salla ${ }^{1 *}$, AVN Swamy ${ }^{1}$ and VV Basava Rao ${ }^{2}$. \\ 1. Dept. Of Biotechnology,Chaitanya Bharathi Institute of Technology, Gandipet, Hyderabad-500075. \\ 2. Dept of Chemical Engg, OU College of technology, Hyderabad.
}

\section{Manuscript Info}

\section{Manuscript History}

Received: 31 October 2016

Final Accepted: 01 December 2016

Published: December 2016

Key words:-

Dairy wastewater; Aerobic treatment, Biodegradation, Mixed culture bacteria, Fluidized bed Bio reactor.

\section{Abstract}

A fluidized bed biological reactor was developed for the treatment of dairy wastewater. The aerobic treatment of dairy waste water was performed experimentally in fluidized bed reactor (FBR) using mixed culture bacteria. The characteristics of dairy waste water were studied. The reactor influent was raw dairy wastewater $(\mathrm{pH} \mathrm{7.68,} \mathrm{TSS} 234$ $\mathrm{mg} / \mathrm{l}$, Total dissolved solids $1190 \mathrm{mg} / \mathrm{l}$, COD 3,026 mg/l, BOD 1482 $\mathrm{mg} / \mathrm{l}$, oil and grease $23.80 \mathrm{mg} / \mathrm{l})$. The results show that the final COD was around $159 \mathrm{mg} / \mathrm{L}$ and the percentage reduction in COD is $95 \%$. Using mixed culture bacteria as a support material, the COD, BOD and TSS reduction and increase in $\mathrm{pH}$ of the dairy treated effluent were estimated to justify the fluidized bed bioreactor as an efficient method which uses less energy, less space for the effective biodegradation of the dairy waste water.

Copy Right, IJAR, 2016,. All rights reserved.

\section{Introduction:-}

The industrial growth of the country resulted in economic growth at the same time it has adversely affected the environment. The industrial discharges are given due importance at present since they are polluting both land and inland surface water streams. This eventually led to the degradation of the environment to a great extent ${ }^{[1]}$. Dairy industry is one such industry which has been damaging the environment by discharging partially treated wastewaters ${ }^{[2]}$. Eutrophication of surface waters is caused by the nutrients present in dairy effluent ${ }^{[3]}$. It is essential to consider dairy wastewater because it has contaminants which cause pollution ${ }^{[4]}$. Activated sludge process has been tried by for treating the dairy waste waters which contain high COD and suspended solids. The nitrogen and phosphorous requirements of the activated sludge process may be met from the waste water itself. The manufacturing processes of dairy industries vary from dairy to dairy ${ }^{[5]}$. The wastewater generated by the dairy industry contributes to pollution significantly and it contains mainly organic components ${ }^{[3,5]}$. The demand for milk and its products are increasing with the increasing population in India and this has resulted in the establishment of a number of dairy industries. However, the milk production in India has enhanced in the past few decades from a low volume of ${ }^{[6,7]}$ million tons in 1950s to 110 million tons in 2010.The potential for dairy sector in India has a good opportunity to influence the world dairy market in the long run, provided, state of art technology is used ${ }^{[7]}$. The predominance of water consumption in dairy industry has eventually led to generation of large volumes of wastewater. The typical wastewaters emanated per liter of milk produced would be 6 to 10 liters ${ }^{[8]}$. Approximately 1 to $2 \%$ of the total milk processed is wasted in a dairy industry ${ }^{[9]}$. The composition of the waste waters in terms of concentration and organic matter varies significantly in dairy industry ${ }^{[10]}$. And, this variation may be due to the operations and products changing from time to time ${ }^{[11]}$. The constituents such as casein, lactose, inorganic salt, besides detergents

Corresponding Author:- Sumithra Salla.

Address:- Dept. Of Biotechnology,Chaitanya Bharathi Institute of Technology, Gandipet, Hyderabad500075 
and sanitizers used for washing are found in dairy wastewaters ${ }^{[12]}$. Dairy wastewaters may also comprise dissolved sugars, proteins, fats and possibly residues of additives which contribute to organic load of wastewaters generated ${ }^{[13]}$. The high organic load, dairy wastewaters lead to rapid degradation and results in the depletion of DO (dissolve oxygen) level of the receiving water streams and become the propagation place for mosquitoes and flies carrying malaria and other perilous disease such as, yellow fever, chicken guinea and dengue fever ${ }^{[14]}$. The dairy waste has a characteristic butyric acid odor ${ }^{[15]}$. The dairy wastewaters are rich in fats, oils and greases (FOGs) also may have negative impacts on wastewater treatment systems ${ }^{[16]}$ like causing foul odors, blockage of pipes and sewer lines. Volatile fatty acids (VFA) are among the most abundant volatile organic compounds in dairy manure and are associated with odor nuisance ${ }^{[17]}$. Ammonia nitrogen is present in milk and about 30 to $50 \mathrm{mg} / \mathrm{L}$ of nitrogen is found in wastewater stream ${ }^{[18]}$. Presence of nitrate may cause methemoglobinemia if converted to nitrite ${ }^{[3]}$ and contaminates groundwater. Therefore, treatment of dairy waste water is essential ${ }^{[19]}$. The Characteristics of raw effluent collected from the dairy industry in Hyderabad are given in the Table 1.

\section{Material and Methods:-}

\section{Reactor set up:-}

The fluidizing column is made up of acrylic, which has a height of $660 \mathrm{~mm}$, an inner diameter of $90 \mathrm{~mm}$ and an outer diameter of $260 \mathrm{~mm}$. Air is sparged using a compressor and the flow rate is controlled by a rotameter which is of the range $0.4-4 \mathrm{lit} / \mathrm{min}^{[2]}$. Similarly, the effluent is fed into the column by using a mono-block motor of $0.25 \mathrm{Hp}$, and the liquid flow rate is controlled by using a rotameter which is of the range $0-500 \mathrm{lit} / \mathrm{hr}$.

\section{Sample collection and preservation:-}

The dairy effluent was collected from a Vijaya -Telangana Dairy, located near Tarnaka, Hyderabad and stored in a refrigerator at $3^{0} \mathrm{C}$ to prevent biodegradation.

\section{Experimental Setup:-}

The experimental setup is shown in the Figure 1. The set up consists of inner direct fluidized core of height $660 \mathrm{~mm}$ and diameter $260 \mathrm{~mm}$. Air is sparged using a compressor and the flow rate is controlled by using a rotameter which is of the range $0.4-4$ lit/min. The effluent was fed into the column by using a mono - block motor of $0.25 \mathrm{Hp}$, and the flow rate was measured by using a rotameter with range $0-500 \mathrm{~L} / \mathrm{h}$.

\section{Experimental Procedure:-}

The inoculated microorganism acts on the organic and inorganic constituent of waste water for their metabolic activity. The organisms were incubated for a time interval of 2-3 weeks for the growth of biomass. The effluent was pumped in to the column and the flow rate was monitored using a rotameter and the compressed air is sent through a regulator. The truncated cone expansion provided at the inlet of the reactor ensure minimal pressure drop and the grid provides proper mixing of gas and liquid. The parameters which influence the reduction rate of COD in the effluent are temperature, $\mathrm{pH}$, and concentration of the microorganisms.

\section{Result and Discussion:-}

The Fluidized bed bioreactor treating dairy waste water showed high process stability. Results presented have clearly shown that it is possible to effectively degrade dairy waste water. High surface area of the viable biomass inside the reactor is maintained during fluidization. Main factor responsible for degradation was the biomass, although, some degradation may occur due to suspended active cells when the reactor was operated in a mixing regime. For dairy effluent, a maximum COD removal efficiency of $95 \%$ is achieved in the fluidized bed reactor (FBR). Fig 2 represents the \% COD removal at various hydraulic retention time (HRT). It is observed that the COD reduction decreased with HRT. Higher HRT decreases flow rate of the waste water through the reactor and biomass. Thus, increases the mass transfer and leads to efficient degradation of waste. This observation is in good agreement with previous reports ${ }^{[20,21]}$. When the HRT increased from 0.5 to $2 \mathrm{~h}$, percentage COD removal increased from $86 \%$ to $98 \%$.

\section{Conclusion:-}

Based on the analysis and interpretation of the experimental results for biodegradation of dairy waste water in fluidized bed bioreactor the following conclusion is drawn. Results presented in this paper have clearly shown that it is possible to degrade effectively dairy waste water, since operational conditions such as good aeration and mixing due to recycle, are assured in order to maintain enough viable biomass inside the reactor during fluidization. The 
COD removal efficiencies are in the range of 92 to $95 \%$. The final treated wastewater has the COD in the range of 150 to $240 \mathrm{mg} / \mathrm{l}$. The present studies proved that the fluidized bed reactor has high efficiency in treating the organic loads. Also, the time taken for degradation is less, hence the fluidized bed reactor can be used to treat dairy wastewaters and there is a scope for scaling up for industrial level.

\section{Tables:-}

\section{Characteristics of raw effluent:-}

Table 1:- The characteristics of Dairy waste water.

\begin{tabular}{|l|l|l|}
\hline Colour & & Light brown \\
\hline Odour & & Foul \\
\hline pH & & 7.68 \\
\hline Total dissolved solids & & $1190 \mathrm{mg} / \mathrm{l}$ \\
\hline Total suspended solids & $234 \mathrm{mg} / \mathrm{l}$ \\
\hline Chemical oxygen demand & $3026 \mathrm{mg} / \mathrm{l}$ \\
\hline Biochemical oxygen demand & & $1482 \mathrm{mg} / \mathrm{l}$ \\
\hline Oil and grease & & $23.80 \mathrm{mg} / \mathrm{l}$ \\
\hline
\end{tabular}

6. Figures:-

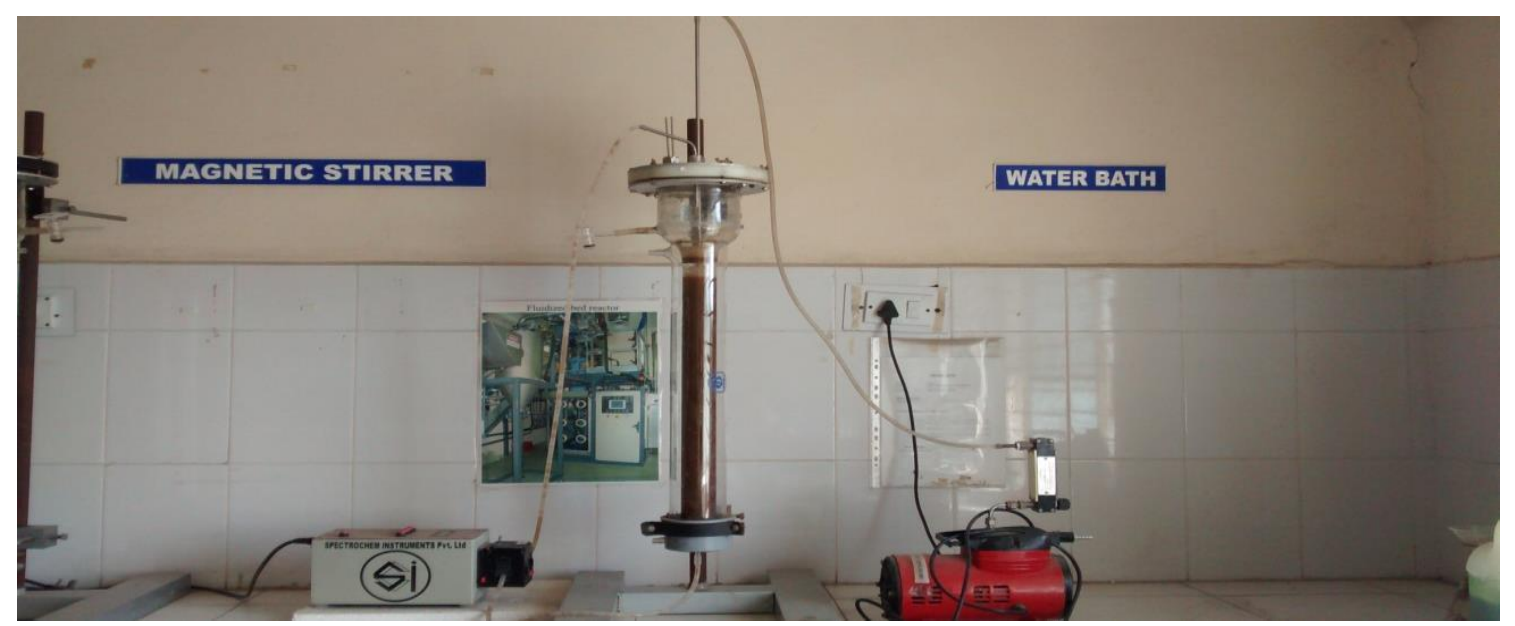

Figure 1:- Schematic diagram of Fluidized bed reactor (FBR)

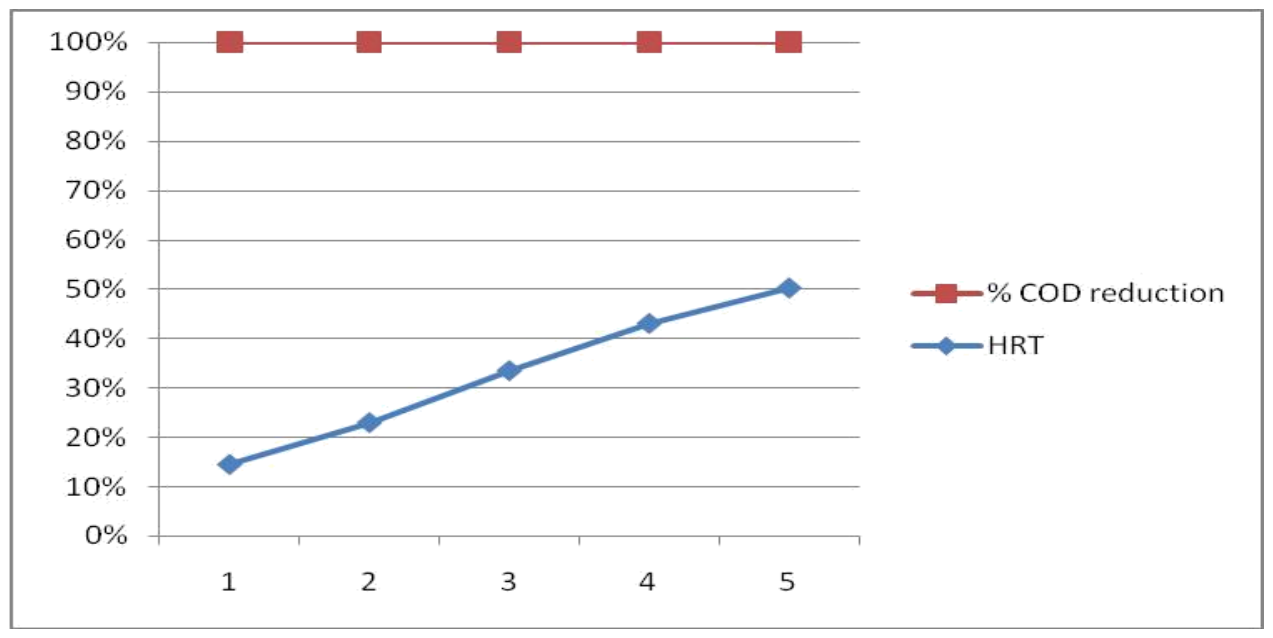

Figure 2:- The COD reduction of dairy wastewater with different HRTs 


\section{References:-}

1. P.K. Chhonkar, S.P. Datta, H.C. Joshi, H. Pathak, Impact of industrial effluents on soil health and agriculture Indian experience: Part-II-Tannery and textile industrial effluents, J. Sci. Ind. Res 59 (2000) 446-454.

2. S.G. Ganapathy, R. Baskaran, P.M. Mohan, Microbial diversity and bioremediation of distilleries effluent, J. Res. Biol 3 (2011) 153-162. 0

3. J.P. Kushwaha, V.C. Srivastava, I.D. Mall, An overview of various technologies for the treatment of dairy wastewaters, Crit. Rev. Food Sci. Nutr. 51 (2011) 442-452.

4. M. Meul, F. Nevens, D. Reheul, Validating sustainability indicators: Focus on ecological aspects of Flemish dairy farms, Ecol. Indic. 9 (2009) 284-295.

5. L.A.H.M. Verheijen, D. Wiersema, L.W. Hulshoff Pol, J. De Wit, Management of Waste from Animal Product Processing, International Agriculture Centre, Wageningen, The Netherlands, 1996.

6. A. Chawla, N. Chawla, Y. Pant, Milk and Dairy Products in India - Production, Consumption and Exports: Introduction, Hindustan Studies \& Services Ltd., India, 2009 (Retrieved 3rd August 2014)

7. 〈http://www.hindustanstudies.com/files/ dairysept09report.pdf〉

8. V.P. Sharma, A. Gulati, Trade liberalization, market reforms and competitiveness of indian dairy sector", MTID

9. Discussion Paper No.61, Markets, Trade and Institutions Division, International Food Policy Research Institute (IFPRI), Washington, D.C., 2003.

10. A.S. Kolhe, V.P. Powar, Physico-chemical analysis of effluents from dairy industry, Recent Res. Sci. Tech 3 (2011) 29-32.

11. G.R. Munavalli, P.S. Saler, Treatment of dairy wastewater by water hyacinth, Water Sci. Technol. 59 (2009) 713-722.

12. B. Farizoglu, S. Uzuner, The investigation of dairy industry wastewater treatment in a biological high performance membrane system, Biochem Eng J. 57 (2011) 46-54.

13. A.S. Khojare, M.R. Patil, A.R. Sarode, P.G. Wasnik, Membrane process: An emerging solution for effluent

14. treatment in dairy and food plant. Proceedings of UGC Sponsored National Conference on 'Hydro-chemical, Bio-chemical Studies and Environmental Pollution' Aurangabad, 2002.

15. A.S. Kolhe, S.R. Ingale, R.V. Bhole, Effluents of dairy technology, Int. Res. Jr. Sodh, Samiksha and Mulyankan 5 (2009) 459-461.

16. H.F. Castro, A.A. Mendes, Some biochemical aspects of the anaerobic degradation of dairy wastewater, Wat. Res 29 (2004) 1549-1554.

17. D. Kumar, K. Desai, Pollution abatement in milk dairy industry, Curr. Pharma Res 1 (2011) 145-152.

18. V.B. Braio, C.R.G. Taveres, Effluent generation by the dairy industry: preventive attitude and opportunities, Braz. J. Chem. Eng. 24 (2007) 487-497.

19. P. Becker, D. Koster, M.N. Popov, S. Markossian, G. Antranikian, H. Markl, The biodegradation of olive oil and treatment of lipid-rich wool wastewater under aerobic thermophilic condition, Water Res. 33 (1999) 653660.

20. L.H. Page, N. Ji-Qin, A.J. Heber, N.S. Mosier, X. Liu, H.S. Joo, P.M. Ndegwa, J.H. Harrison, Characteristics of volatile fatty acids in stored dairy manure before and after anaerobic digestion, Biosys. Eng. 118 (2014) 16-28

21. P. Soederhjelm, B. Lindqvist, The ammoniacontent of milk as an indicator of its biological deterioration or ageing, In Milchwissenschaft 35 (1980) 541-543.

22. Souza R.R., Bresolin I. T. L., Bioni T. L., Gimenes M. L. and Dias-Filho B. P., The Performance of a three phase fluidized bed reactor in treatment of waste water with high organic load, Brazilian. J.Chem.Engineer., 21, 219 - 227, (2004).

23. Hariklia N. Gavala, Felipe Alatriste-Mondragon, Reza Iranpour, Birgitte K. Ahring, Biodegradation of phthalate esters during the mesophilic anaerobic digestion of sludge Chemosphere., (2003), 52, 673-682.

24. Herbert H. P., Fang H. Q. Yu., effect of hrt on mesophilic acidogenesis Of dairy wastewater, J.Environ. Engineer., (2000), 1145-1148. 